\title{
La Guerra de Malvinas según las Caricaturas de Hermenegildo Sábat en Clarín
}

\section{Burkart, Mara}

Resumen:

Este trabajo propone analizar las caricaturas producidas por Hermenegildo Sábat, dibujante del diario Clarín, durante el conflicto por las Islas Malvinas desatado por la dictadura militar argentina en abril de 1982 y que concluyó dos meses después con una estrepitosa derrota militar. Concebida en su sentido moderno, la caricatura es un instrumento visual poderoso y eficaz a la hora de continuar los conflictos políticos por medios simbólicos. Entonces: ¿Qué sucedió con la caricatura en uno de los principales diarios nacionales durante la Guerra de Malvinas? ¿Se convirtió en un arma más al servicio de la causa nacionalista o posibilitó nuevas y críticas interpretaciones del conflicto?

\section{Cuadernos del Centro de Estudios de} Diseño y Comunicación N ${ }^{074}$

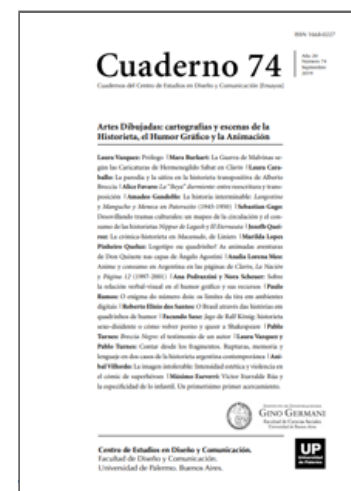

ISSN: 1668-0227

Artes Dibujadas:

cartografías y

escenas de la

Historieta, el Humor

Gráfico y la

Animación

Año XX, Septiembre 2019, Buenos

Aires, Argentina | 256 páginas

descargar PDF ver índice de la publicación

Ver todos los libros de la publicación

compartir en Facebook

Nuestra hipótesis es que las

caricaturas de Sábat dan cuenta de la clausura del espacio público entre el momento de la llamada "recuperación" y la guerra propiamente dicha, y se sugiere que pudieron habilitar un resquicio crítico.

Palabras clave: Guerra de Malvinas - caricatura - Hermenegildo Sábat.

$\left(^{*}\right)$ Socióloga, Magíster en Sociología de la Cultura y Análisis Cultura por el IDAES-UNSAM, Doctora en Ciencias Sociales por la UBA. Investigadora asistente del CONICET con sede en el Instituto de Estudios de América Latina y el Caribe y coordinadora del Grupo de Estudios Cultura, Medios y Sociedad en América Latina (GECUMESAL).

La Guerra de Malvinas es indisociable de la dictadura militar que gobernó la Argentina desde el golpe de Estado de marzo de 1976 a diciembre de 1983. A fines de 1981, las fuerzas armadas designaron como nuevo presidente de facto al general Leopoldo Fortunato Galtieri, representante del ala militar menos propensa a una 
apertura democrática. Galtieri llegaba al poder después de un golpe palaciego que destituyó a Roberto Viola, exponente del sector aperturista. La crisis política del autoproclamado "Proceso de Reorganización Nacional" se había hecho pública a lo largo de 1981, mientras la sociedad civil había comenzado a alzar su voz contra el régimen y a reorganizarse de forma más sistemática que en los años anteriores. En 1982, el clima de creciente descontento social fue en aumento y su momento más álgido fue la movilización a Plaza de Mayo del 30 de marzo convocada por la CGT-Brasil. La respuesta del gobierno militar fue una dura represión que se cobró centenares de heridos y miles de presos. Era la primera gran movilización contra la dictadura y todos los diarios informaron sobre lo sucedido. En ese contexto, Galtieri sorprendió a la sociedad argentina con el anuncio de la "recuperación"1 militar de la soberanía sobre las Islas Malvinas. Se trataba de nuevo intento de inyectarle iniciativa al "Proceso".

La Guerra de Malvinas quedó registrada en diversos soportes visuales gracias a los medios de comunicación de masas. Imágenes de televisión, fotografías, publicidades, caricaturas, chistes gráficos e historietas conforman un corpus visual variado y rico sobre los acontecimientos de aquellos meses y sus protagonistas. A partir de un paradigma que concibe a la cultura como un espacio privilegiado de producción de visiones del mundo, las cuales entran en disputa para definir el orden y sus expresiones legítima, este trabajo se propone analizar las caricaturas que aluden a la disputa por Malvinas realizadas al calor de los acontecimientos por Hermenegildo Sábat para el diario Clarín.

Entendida en su sentido moderno, la caricatura es la distorsión cómica de una persona. Es el arte de exagerar (caricare: "cargar") a los fines de rebajar, desenmascarar y de restarle títulos de autoridad a quien se eligió como blanco. En su uso político, ese arte se dirige a satirizar especialmente a la clase dirigente. Para Ernst Gombrich ([1940] 2001, p. 6), la caricatura tiene poderes mágicos y subversivos asociados a su función pedagógica en tanto enseña "a verlo de manera novedosa, a verlo como una criatura ridícula. [...] Contra este hechizo hasta el más poderoso queda impotente".

Para que la caricatura sea eficaz, el dibujante debe ser capaz de involucrar al espectador y convertirlo en cómplice en contra de un enemigo al que se torna cómico al exponerlo y volverlo inferior y despreciable. Además de atacar, la caricatura cohesiona y tranquiliza a quienes ya están convencidos, estableciendo conexiones entre lo familiar y lo no familiar a partir del uso de metáforas visuales. (Gombrich, 2003)

Estas características de la caricatura la convierten en un instrumento visual poderoso y eficaz a la hora de continuar los conflictos por medios simbólicos, en especial, en contextos de guerra y de dictadura. ¿Qué sucedió con la caricatura durante la Guerra de Malvinas? ¿Se convirtió en un arma al servicio de la causa nacionalista? ¿Posibilitó nuevas y críticas interpretaciones del conflicto? ¿A quiénes "embrujó" Sábat? Nuestra hipótesis es que las caricaturas de Sábat dan cuenta de la clausura del espacio público entre el momento de la llamada "recuperación" y la guerra propiamente dicha, y se sugiere que sus caricaturas pudieron habilitar un resquicio crítico.

A los fines de responder a los interrogantes planteados, dividimos el artículo en cuatro secciones: la primera, presenta brevemente a Sábat y al diario Clarín en relación a la dictadura militar; en las siguientes se presenta el análisis de las caricaturas siguiendo un orden cronológico. De este modo, la segunda parte está dedicada al momento de la llamada "recuperación" de las Islas que se extiende desde el 2 de abril a los primeros días de 
mayo; la tercera, se centra en la guerra propiamente dicha, y la cuarta, en la derrota y la inmediata posguerra. Por último, presentamos unas reflexiones finales a modo de conclusión.

\section{Sábat, Clarín y la dictadura militar}

Hermenegildo Sábat comenzó a ilustrar las secciones centrales de Clarín en 1973, y lo sigue haciendo hasta el día de hoy. Previo a ello, este uruguayo nacido en 1933 colaboró con la revista Primera Plana y con The Buenos Aires Herald, se consagró en 1971 con su trabajo para el diario La Opinión donde impuso su estilo: un trazo suelto y experimental que prescinde de palabras (aunque los editores del diario agreguen la leyenda con los nombres de los personajes retratados). Esta ausencia de palabras, su sensibilidad casi surrealista y su negativa a explicitar algún significado a los elementos que incorpora a sus dibujos, vuelven a su obra por momentos críptica para el censor y para el lector medio de un diario masivo como Clarín2 .

La llegada de Sábat a Clarín fue parte de una renovación visual y humorística del matutino. Ese mismo año se sumaron Caloi, Crist, Fontanarrosa y Bróccoli a la contratapa del diario, consagrada al humor gráfico. Publicados en blanco y negro, los retratos caricaturescos de Sábat estaban rodeados por extensas notas periodísticas, o estaban cerca de fotografías y anuncios publicitarios, todos también en blanco y negro. Las caricaturas de Sábat se alternaban en ese entonces con los cartoons3 de Landrú en las secciones Política, Economía, Internacionales y, a partir de 1981, acompañaron la columna Panorama Político que escribían los principales periodistas del matutino. Si algo es común a todos estos dibujantes, es la producción diaria de imágenes. En tanto caricaturas políticas, entonces, estamos hablando de imágenes que se elaboran al calor de las noticias del día. Es por este motivo que los dibujantes, y Sábat no es una excepción, suelen armar series a partir de algunos elementos que se reiteran durante algún tiempo, mientras que otros más coyunturales cambian.

En los años setenta, Sábat ya era reconocido por sus colegas como un "maestro" 4 y se convirtió en uno de los dibujantes más destacados de la prensa nacional donde, además de Landrú, también descollaba Andrés Cascioli, responsable de las portadas de las principales revistas satíricas de aquel entonces: Satiricón, Chaupinela y $\mathrm{HUM} \otimes$.

El golpe de Estado supuso que la caricatura política se retirara de las principales secciones del matutino a otras menos comprometidas políticamente como eran Internacionales, Economía y al suplemento Cultura y Nación. A poco tiempo volvió tímida y gradualmente, como si los editores estuviesen identificando los márgenes de lo permitido por un régimen que apostó a la ubicuidad de la censura y de la represión al no explicitar sus reglas de juego. En Clarín, la primera caricatura personal en publicarse después del Golpe fue hecha por Sábat. Esto ocurrió el 7 de abril de 1976 y el retratado fue Guillermo Bravo, flamante Secretario de Comercio, es decir, una figura de segunda línea de la nueva administración. Dos días después, Sábat retrató al ministro de Economía, José Alfredo Martínez de Hoz y por unas semanas la galería de retratados se amplió con la incorporación de otros funcionarios civiles y militares de más alto rango. Sin embargo, al poco tiempo se circunscribió a círculo de los posibles retratados a los miembros del equipo económico. Estos protagonizaron las caricaturas de Clarín entre 1976 y mediados de 1978, cuando en medio de la coyuntura del Campeonato Mundial de Fútbol, el matutino publicó la primera caricatura del presidente de facto Jorge R. Videla, también realizada por Sábat (Clarín, 30/07/1978). Sin embargo, a las pocas semanas de aquella primera imagen, dejó de ser retratado y los miembros del equipo económico volvieron a protagonizar las caricaturas de dibujante. Videla recién volvió a ser 
caricaturizado en 1980, a propósito de la crisis política y económica que amenazaba con derrumbar al "Proceso"5 .

Recientemente ha habido excelentes estudios sobre el diario Clarín, soporte de estas caricaturas, y sobre su relación con la dictadura militar y la gravitación que conquistó en ese entonces en el espacio periodístico y mediático, basta citar a Marcelo Borrelli (2010), Martín Sivak (2013) y Florencia Levín (2013). Todos ellos coinciden que desde mediados de los años setenta, el matutino fundado por Roberto Noble en 1945 era el referente de la clase media urbana y el de mayor tirada a nivel nacional. En 1982, tenía un promedio de 611.000 ejemplares vendidos, ampliando los 575.000 que había vendido en 19816 .

En cuanto a su posicionamiento político, Clarín presentó como inevitable el golpe de Estado y mostró anuencia con la necesidad de refundar la sociedad argentina que plantearon los militares, aunque sostenía que ésta debía ser a través de "soluciones desarrollistas" (Borrelli, 2010). Si bien actuó como un "juez crítico" de la política económica del ministro Martínez de Hoz, no vio impedimento en asociase al Estado junto a los diarios La Nación y La Razón para la producción monopólica de papel en Papel Prensa S.A. El diario osciló entre acompañar y expresar algunas críticas al régimen militar como sucedió en 1979, cuando su directora, Ernestina Herrera de Noble, celebró junto a Videla el año de la obtención del Campeonato Mundial de Fútbol y al mes siguiente, publicó la carta "Desventuras en el País-Jardín-de-Infantes" de la cantautora infantil María Elena Walsh que denunciaba la censura y la infantilización de la sociedad por parte de la dictadura.

A fines de 1981, el diario se despojó de su prédica desarrollista (Sivak, 2013) y con la llegada de Galtieri al poder, Clarín omitió las críticas al gobierno y como toda la prensa masiva, apoyó la invasión a las Malvinas. Sin embargo, Sábat demostró márgenes de autonomía y en algunas ocasiones se burló de del nuevo dictador como cuando intentó conseguir apoyos políticos civiles y para ello organizó un gran asado en la localidad de Victorica, provincia de La Pampa. Más audaz aún, fue cuando en una caricatura sugirió que no habría justicia bajo su mandato en relación a un tema delicado para las fuerzas armadas como era la investigación judicial por las violaciones a los derechos humanos que los organismos y los familiares de las víctimas venían reclamando. En la caricatura, Galtieri personifica una justicia que lleva una túnica pero que no es ciega (la venda no le cubre los dos ojos), no le importa ser justa (la balanza que lleva es bien pequeña) y exhibe una gran espada bien afilada (Clarín, 28/02/1982).

Sábat ante la "recuperación" de las Islas Malvinas

El 2 de abril de 1982, un comunicado en cadena nacional anunció a la sociedad argentina que las fuerzas armadas habían "recuperado" las Islas Malvinas, Georgias y Sandwich del Sur. Ese mismo día miles de argentinos se acercaron a la Plaza de Mayo a vitorear "Argentina, Argentina" y Galtieri salió al balcón de la Casa Rosada a encontrarse con esa multitud. La televisión transmitió ese encuentro. Al día siguiente, la gran prensa reprodujo fotografías en blanco y negro de lo que llamaron "Euforia popular" o "Alborozo ciudadano" (Clarín, 03/04/1982; La Nación, 03/04/1982). Las imágenes de los policías y militares reprimiendo a los trabajadores en las calles de la ciudad de tres días atrás cedieron a las imágenes de unidad y fraternidad promovidas por la interpelación nacionalista.

En contraste con las imágenes televisivas que mostraron a Galtieri sonriente ante las personas que se habían congregado en la Plaza, desde Clarín, la caricatura de Sábat aludió con sarcasmo al encuentro entre gobierno y 
sociedad, o entre militares y civiles. Desde su lugar de retratista cómico, hizo foco en el líder que encabezaba la gesta patriótica de devolverle al país el pedazo de territorio arrebatado hacía casi ciento cincuenta años. En la imagen creada por Sábat, Galtieri continuaba una genealogía nacional y popular que comenzaba con Carlos Gardel y seguía con Juan Domingo Perón (Clarín, 04/04/1982, Ver Figura 1). La sonrisa gardeliana y la peronista se prolongaba en la mueca de Galtieri. También era una continuidad el gesto de alzar los brazos y poner los pulgares en alto para formar una guirnalda triunfal y celebrar el reencuentro nacional, y olvidar la represión del 30 de marzo y la masacre que la dictadura había perpetrado desde su instauración en 1976.

Según Rosana Guber (2012, p. 37), Galtieri “era mucho más que Perón” porque había logrado reunir en la emblemática plaza a todos los argentinos, como él mismo proclamó: "sin distinción de los sectores o banderías [... que] han luchado por la reivindicación de nuestros derechos" (Clarín, 3/04/1982). Sábat ponía en evidencia esa pretensión de Galtieri de querer superar a Perón y su caricatura lo expone en la contradicción de ser parte de un régimen que se había empecinado por eliminar del imaginario, la memoria social y de la política todo gesto o actitud carismática que remitiese al peronismo. Con la puesta en escena del 2 de abril, Galtieri se había transformado de un día para el otro en el nuevo líder carismático de la Argentina. Sábat parecía citar a Marx cuando dice "La historia se repite primero como tragedia y después como farsa": si Gardel había sido la historia, Perón había sido la tragedia y Galtieri era la farsa.

La caricatura creada por Sábat se publicó junto con la nota de opinión "El desembarco del consenso" de Joaquín Morales Solá que se congraciaba con el régimen por haber dejado atrás el "vacío de consenso" por el cual "debió reprimir con dureza inusual los repudios" (Clarín, 4/04/1982). El diario así avalaba esta posición ambigua y quedaba en el lector qué interpretación hacer de los hechos.

La causa de Malvinas tuvo un gran apoyo ciudadano y el aval de todas las organizaciones de la sociedad civil. Las dirigencias eclesiástica, empresarial, sindical, partidarias, ex presidentes, periodistas y personalidades de la cultura y del deporte expresaron públicamente su adhesión7. Como sostienen Novaro y Palermo (2003, p. 440), "si la ocupación se consolidaba, el costo de haberse mantenido al margen sería abrumador; y si terminaba mal, la unanimidad reinante diluiría el costo de haber adherido de un modo parejo".

Los medios de comunicación debieron acatar las Pautas a tener en cuenta para el cumplimiento del Acta de la Junta Militar disponiendo el control de la información por razones de seguridad, que exigía evitar toda información que "reste credibilidad y/o contradiga la información oficial" y que "sin provenir de fuente oficial, se refiera a operaciones militares argentinas" (Blaustein y Zubieta, 1998, p. 470). Como señala Lucrecia Escudero (1996, p. 177), en ellos se entremezclaba "censura y autocensura, voluntad de informar y producción ficcional". Sin poder cuestionar la orden, muchos expresaron adhesión, gran fervor nacionalista y un triunfalismo arrollador. La televisión se sumó a esa intensa campaña, hubo programas especiales como aquel de 24 horas dedicado a la colecta del "fondo patriótico" el cual, como después se sabría, nunca llegó a los combatientes en las islas.

El espacio público que en 1981 había mostrado signos visibles de revitalización, nuevamente se clausuró frente a los discursos nacionalistas y triunfalistas. Clarín se plegó al discurso oficial de la "recuperación de la soberanía violada por el colonialismo" y no criticó abiertamente la responsabilidad del gobierno militar en la ocupación. Se trataba de un acto justo e incuestionable, y la pluma de Sábat se plegó a esta operación simbólica por la cual se reavivaba la reivindicación anticolonial. En el matutino se podía ver cómo una mano le sacaba la silla donde hacía 133 años estaba sentada la reina Victoria del Reino Unido (1837-1901) o a Galtieri velar por el sueño de 
Juan Manuel de Rosas o a este último desafiar con firmeza y decisión a la Reina Victoria ante el secretario de Estado estadounidense, Alexander Haig, que intentaba distanciarlos (Clarín, 7/04/1982, 3/04/1982, 8/04/1982). Por un lado, se aludía a la vigencia del viejo colonialismo inglés y por otro, se exaltaba el desafío y la irreverencia de una joven y envalentonada Nación Argentina hacia la vieja potencia imperial.

Sin embargo, al poco tiempo este desfile de personajes históricos cedió su lugar al panteón tanguero que se convirtió en el recurso visual predilecto de Sábat para su interpretación gráfica del conflicto por Malvinas. El dibujante apeló a las imágenes que había creado para sus dos libros dedicados a la música porteña: Al troesma con cariño de 1971 y Tango mío de 1981, y convirtió esta célebre iconografía en el símbolo de la argentinidad en el marco del conflicto por la soberanía de Malvinas. Carlos Gardel comenzó a representar indistintamente a las autoridades militares como a la Argentina unida más allá de las banderas partidarias e ideológicas. La unidad era cultural antes que política, y era porteñocéntrica y "de exportación". El tango era la carta de presentación de Argentina ante el mundo y Sábat, que había publicado uno de sus libros sobre sus figuras emblemáticas en España, lo sabía. De este modo, una lectura audaz puede entender a Gardel como la máscara de una Argentina que decía estar unidad, pero en realidad no lo estaba. Esta ambivalencia estará constantemente presente en la obra de Sábat.

En el diario, las representaciones cómicas de los ingleses quedaron en manos de Landrú y la planta de humoristas que publicaba en la contratapa del diario8, en cambio, Sábat fue el responsable de la crónica visual a partir de lo que sucedía en las altas esferas del poder a lo largo del devenir del conflicto con el Reino Unido por las Islas Malvinas. Margaret Thatcher fue uno de los blancos predilectos de la caricatura. Sábat la retrató angustiada, con lágrimas en los ojos y, en algunos casos, indecisa: sus pies van para un lado y su torso y cabeza, para otro. También reforzó sus atributos asexuados y de señora mayor, como su papada y la joroba en su espalda. El dibujante la hizo compartir escenas con los más eximios músicos de los años de oro del tango argentino desde Aníbal Troilo y Homero Manzi, creadores del tango Sur (Clarín, 17/04/1982), a Pedro Laurenz y Pedro Maffia, los bandoneonistas de la Guardia Nueva. En cada entrega los músicos cambiaban pero la escena era parecida: estos tocaban sus instrumentos y, a sus espaldas o a un costado, Thatcher caminaba sin prestarles atención (Clarín, 22/04/1982). Si bien esas fueron semanas de frenéticas negociaciones diplomáticas, para Sábat no había diálogo sino que cada uno atendía su juego y, mientras los argentinos están estáticos y se lamentaban con el bandoneón, la primera ministra estaba en constante ir y venir.

La caricatura del 18 de abril rompió esa supuesta indiferencia. En la imagen, Celedonio Flores le habla al oído a Carlos Gardel y le señala a la primera ministra que está a sus espaldas (Ver Figura 2). Tampoco hay diálogo pero el lector lo podía imaginar: "Carlos, mirá, ahí está Margot", en un tono moralmente condenatorio en alusión a la muchacha decente y humilde que se había acomodado y corrompido para escapar de su destino de pobreza, según narra el tango que ambos compusieron en 1921 junto a José Ricardo.

Sábat remarcada que Margaret Thatcher no actuaba según las expectativas de los militares argentinos y, como dice el tango, se había ido con quienes le prometieron "pasarla de bacana":

hasta el nombre te han cambiado como has cambiado tu suerte: Ya no sos mi Margarita... ¡Ahora te llaman Margot!

Ahora vas con los otarios a pasarla de bacana a un lujoso reservado del Petit o del Julien... 
La cúpula militar argentina había especulado que la toma de las Islas por la fuerza no supondría un enfrentamiento bélico sino que el Reino Unido se vería resignado a negociar con ella, pero las decisiones que salían de Londres fueron en la dirección contraria (Novaro y Palermo, 2003, p. 419; Guber, 2012, p. 29). Thatcher solicitó apoyo a los Estados Unidos y a la OTAN para evitar lo que consideraba una usurpación por parte del gobierno argentino. Este y buena parte de la prensa y la sociedad argentina vivieron en ese gesto de la primera ministra un desplante, y Sábat no fue el único en apelar a la imaginería del tango para representarlo, Cascioli en su caricatura para $H U M \circledR$ también lo hizo ( $\mathrm{H} \mathrm{n}^{\circ} 80$, mayo de 1982). En la primera portada que la revista le dedicó al tema, la asociación entre Margaret Thatcher y el tango Margot también fue un recurso que Cascioli explotó. Más explícito que Sábat, el director de HUM® caricaturizó a Galtieri y al canciller argentino, Nicanor Costa Méndez, lamentándose por la ida de Thatcher "con los otarios": ambos guitarra en mano, le cantan a la primera ministra "Ya no sos mi Margarita...."9 .

Margot era un recurso metafórico y familiar que permitía aludir a la histórica relación entre Argentina e Inglaterra que -a pesar del colonialismo sobre las Malvinas y varios desentendimientos-, había tenido momentos de estrechos acuerdos y bastaba recordar el pacto Roca-Runciman de 1933 o más recientemente y en otro plano totalmente diferente, el gran interés que había demostrado la prensa masiva argentina por el casamiento entre el sucesor de la corona inglesa y Diana Spencer. En este caso, el conflicto por la recuperación de las Islas quedaba sintetizado y reducido a un desengaño amoroso, narrado en un tango. Las caricaturas podían interpretarse como una burla de la supuesta degradación moral de la primera ministra inglesa y exhibían el lamento del gobierno militar argentino ante sus decisiones. Pero también o capaz es mejor decir, antes bien, ambas imágenes parecen privilegiar el juego cómico alrededor de las coincidencias entre el célebre tango y el nombre de la Thatcher, y la posibilidad de reinterpretar las decisiones políticas de esta última a la luz de la historia de Margot narrada en el tango. De este modo, lo complejo y angustiante que podría ser el desencadenamiento de una guerra se veía matizado por la caricatura, que al asociar aquello con el tango lo convertía en algo familiar y moralmente reprochable.

Sábat ante la guerra contra Inglaterra

Ante la cada vez más certera posibilidad de que la "recuperación" deviniera en guerra se produjo un prudente alejamiento de aquellas posiciones de apoyo declaradas en un inicio por parte de políticos como Raúl Alfonsín y Arturo Illia. Alfonsín fue ajustando su postura a un diagnóstico que preveía una derrota militar si se desataba la acción bélica. Sin embargo, no sucedió lo mismo con la gran prensa. El $1^{\circ}$ de mayo, Clarín anunció en su portada que Gran Bretaña había sufrido pérdidas al intentar desembarcar en las Islas y que Galtieri había declarado que los ingleses "Pagarán un alto precio por la agresión". Al día siguiente, mientras los ingleses hundían el crucero general Belgrano, la caricatura de Sábat aludía al dictador y a sus declaraciones: Gardel serio, con gesto de advertencia se llevaba el dedo índice a un ojo y empujar el párpado inferior hacia abajo (Clarín, 2/05/1982) (Ver Figura 3) En otra imagen, un Gardel sonriente sugería que los ingleses estaban advertidos, sus épocas de piratas exitosos y de gran Metrópoli imperial habían terminado (Clarín, 4/05/1982). En los días siguientes, las caricaturas insistieron en mostrar a un Gardel con una sonrisa inmutable. Ante un triste y resignado George Washington, un Gardel sonriente muestra su "as bajo la manga", en referencia a los apoyos que Argentina había conseguido (Clarín, 8/05/1982). Si Inglaterra tenía a los Estados Unidos como aliados, Argentina tenía a los países latinoamericanos y a los no-alineados que habían leído el conflicto por Malvinas en clave Sur versus Norte. 
A quince días de iniciada la guerra propiamente dicha, Sábat representó la hora de la verdad, el fin de las máscaras: Estados Unidos era aliado de Gran Bretaña. La caricatura retrataba al Zorzal sonriente sacándose una careta de sí mismo porque cara y máscara eran lo mismo; en cambio, detrás de la máscara de Thatcher estaba la cara de Reagan. La Argentina -el gobierno militar-se valía por sí misma, hecho que no generaba angustia ni miedo sino la sonrisa alegre y amigable. Esa misma sonrisa en la cara de Gardel siguió inalterada aun cuando las tratativas diplomáticas se "encaminaban al naufragio", junto a la cara de espanto de la primera ministra inglesa y la de preocupación de Javier Pérez de Cuellar, secretario general de la ONU (Sábat, Clarín, 16/05/1982). Es inevitable preguntarse acerca de qué generaban estas imágenes, ¿reforzaban el optimismo y el triunfalismo imperante o eran vistas como una sonrisa impostada que negaba la realidad? La insistencia de Sábat en la sonrisa grande e inmutable parece habilitar sutilmente una lectura inversa en tanto mueca impostada, máscara que se burla del excesivo optimismo y triunfalismo que se había propagado en la Argentina gracias a la publicidad oficial que el mismo matutino reproducía.

Fue recién a fines de mayo cuando comenzó a vislumbrarse la angustia y la tristeza entre los argentinos. Por primera vez, Margaret Thatcher se tapaba los oídos, ya no quería escuchar a Aníbal Troilo, a quién se le piantaba un lagrimón (Clarín, 20/05/1982). Al poco tiempo, Clarín publicó la última caricatura de Galtieri durante el conflicto armado, en ella era invitado por Humphrey Bogart -en alusión a Reagan- a firmar un documento. Días más tarde el diario anunciaba que la junta militar había rechazado la propuesta y que las negociaciones con los Estados Unidos habían fracasado (Clarín, 25/05/1982, 28/05/1982). El papa Juan Pablo II se convirtió en la nueva esperanza de una mediación en el conflicto (Clarín, 29/05/1982). Con la sonrisa nuevamente en los labios aunque también con una lágrima asomándose en la comisura del ojo, Gardel agradecía esperanzado la intervención papal. Estas negociaciones también fracasaron y las viñetas de Sábat se cubrieron de ráfagas de tinta china, inaugurando una serie de caricaturas dedicadas al escenario bélico propiamente dicho. En ellas no se representó al enemigo externo sino el frente interno: la Nación unida por Galtieri. En la primera de ellas, Gardel se funde en el territorio de las islas en alusión a la dimensión territorial de la Patria (Clarín, 22/05/1982, Ver Figura 4). En las siguientes, el cantautor abraza a Mercedes Sosa, quien a su vez le da la mano a León Gieco (Clarín, 23/05/1982). La unión del tango, el folclore y el rock nacional a través de sus figuras más emblemáticas (recordemos que la dictadura utilizó la canción de León Gieco, Solo de pido a Dios, para movilizar a su favor a la ciudadanía) simbolizaba la unidad de los argentinos. Jóvenes y mayores, hombres y mujeres, Buenos Aires y el llamado "interior" del país estaban unidos para hacer frente a la guerra. Se trataba de una imagen de armonía y consenso que exponía que "ya no había enemigos a la vista 'entre nosotros"' (Guber, 2012, p. 47). Con desconcierto, quienes hasta hacía muy poco habían sido prohibidos y perseguidos eran bienvenidos a la comunidad, y Mercedes Sosa era un ejemplo más que emblemático. La cantante se había tenido que exiliar, sus temas estaban prohibidos y recién pudo volver a cantar en el país en febrero de 1982, gracias a un empresario que desafió las prohibiciones y se animó a conseguirle un escenario10. Otro tanto sucedió con el rock nacional que si bien no fue totalmente prohibido durante la dictadura militar, sí fue perseguido, censurado y las habituales razzias policiales fueron parte del clima represivo en el cual se desenvolvió. A partir del 2 de abril el rock nacional ingresaba a la cultura masiva con todos los derechos garantizados. La prohibición de difundir música en inglés le abrió como nunca las barreras a este sector marginado aunque ya masivo, del campo musical. Pese a estas imágenes de unidad al fragor de la guerra, la sonrisa del Zorzal se hizo insostenible en la secuencia de caricaturas creadas por Sábat. Estrecharle la mano de Fidel Castro era el límite, indicador de que las cosas no andaban bien. Con una lágrima en uno de sus ojos, Gardel representaba la falta de alternativas y que se estaba "conjurando fantasmas", como se tituló la crónica 
que acompañaba a la caricatura y que narraba el paso de Costa Méndez por la reunión de los Países No Alineados en La Habana (Clarín, 4/06/1982). Como había sucedido en el plano interno, ocurría en el externo donde los hasta entonces enemigos declarados del régimen argentino se convertían en amigos contra el imperialismo.

Sábat, la derrota y la posguerra

El 15 de junio los diarios argentinos anunciaron "un alto en el fuego" (La Nación, 15/06/1982) y el "cese del combate" (La Prensa, 15/06/1982). La derrota en Malvinas fue para buena parte de la sociedad tan inesperada y sorpresiva como el anuncio de la "recuperación" del 2 de abril. Pero en este caso el desconcierto inicial se transformó rápidamente en frustración, bronca y en un fuerte repudio hacia los militares. Dos días después, en una ilustración de Sábat, Gardel serio y compungido apoyaba su mano en gesto de compasión sobre el hombro de un hombre anónimo lleno de interrogantes (la imagen mostraba signos de interrogación sobre su cabeza, típicos recursos del comic). Era la primera vez que en un dibujo de Sábat aparecía representado el pueblo, y lo hacía en el extremo inferior izquierdo del recuadro mientras que Gardel ocupaba todo el lado derecho. Ya no había unidad, pueblo y gobierno se escindían. El pueblo quería saber qué había pasado, quería una explicación que por el momento nadie podía o quería dar. La imagen se sumaba al coro de voces que erigió a la sociedad argentina, al pueblo argentino, como víctima inocente de la manipulación del gobierno.

Al día siguiente, el matutino anunció en su primera plana "Cayó Galtieri” y en la caricatura, Sábat dibujó a Gardel, que seguía serio y que se jactaba de ignorar a un Galtieri incapaz de aceptar la realidad tras el fallido acto que intentó hacer en Plaza de Mayo después del rendimiento de las tropas argentinas (Clarín, 18/06/1982). Si hasta entonces Gardel y Galtieri se habían fundido en una misma persona, la derrota los había desdoblado y la sonrisa no quedaba con el primero sino en la cara de Galtieri, que aún con el pulgar en alto, parecía no haberse enterado del catastrófico desenlace de la guerra.

Con el fin de la guerra volvieron a Clarín las caricaturas de las autoridades militares. Sin embargo, Sábat siguió recurriendo a la figura de Gardel para representar a la nación argentina en la nueva coyuntura de la transición a la democracia. Primero, para evidenciar la crisis en que había caído el "Proceso" y que las fuerzas armadas ya no eran la salvaguarda de la Nación sino más bien sus asesinas. En la imagen de Sábat, mientras el Zorzal convalecía en una cama, el teniente general Cristino Nicolaides, flamante comandante en jefe del Ejército y único miembro de la junta militar tras la renuncia de los representantes de la Armada y la Fuerza Aérea, antes que cuidar de la salud del enfermo más bien al encenderle un cigarrillo quería que empeorara o que directamente, muera (Clarín, 1/08/1982. Ver Figura 5). Pero Gardel se recuperó y en diciembre de 1983, nuevamente radiante se sacó el sombrero y saludó afectuosamente, con su enorme y blanca sonrisa al flamante presidente de los argentinos: el radical Raúl Alfonsín que sellaba el retorno a la democracia (Clarín, 11/12/1983).

\section{Reflexiones finales}

El conflicto por las Islas Malvinas acaparó la agenda mediática y la vida cotidiana de los argentinos con distintos niveles de entusiasmo y de involucramiento. En este artículo hemos analizado las caricaturas dedicadas al tema realizadas por Sábat para el diario Clarín. Al tratase de una producción diaria, su obra tuvo un carácter de crónica visual y humorística basada en las acciones y los discursos de las clases dirigentes de los países en conflicto y de los que intervinieron como aliados o que procuraron evitarlo, en especial, los Estados Unidos. 
Durante las semanas en que el conflicto giró en torno a la ocupación militar argentina de las Islas, y pese a la censura que se instauró, Galtieri estuvo en la mira de Sábat. Este se burló de la transformación súbita del dictador en líder populista. Sin embargo, el blanco predilecto de la sátira fue Margaret Thatcher, y el tango -sus personajes y sus letras- el recurso privilegiado para su representación.

Con el paso del tiempo y ante la cada vez más probable definición bélica, las estrategias visuales y cómicas cambiaron. Galtieri y los miembros del gobierno militar dejaron de protagonizar las caricaturas, Sábat los reemplazó por la figura de Gardel. El Zorzal se convirtió en un símbolo omnipresente en las páginas del matutino y entendemos que representó tanto a las autoridades como la unidad nacional que estas se ufanaban de haber alcanzado. La sonrisa inmutable que día tras día los lectores veían en la cara de Gardel, acompañando las buenas y malas noticias en los frentes diplomáticos y bélicos, tiene una doble lectura habilitada por la ambigüedad de la imagen y la risa. En una interpretación trasparente, aludía al optimismo y al triunfalismo que se fomentó desde las altas esferas del poder y que gran parte de los medios reprodujeron, pero también esa inmutabilidad sugiere que era más bien una máscara, una mueca impostada para hacer creer que había un frente interno cohesionado y que se estaba ganando o que había posibilidades certeras de triunfo cuando en verdad estas eran cada vez más difíciles. Es una lástima no contar con datos sobre la recepción de estas imágenes, y en ese sentido, el análisis se centra en las posibles lecturas que las imágenes podrían haber tenido.

Después de la derrota, el espacio público se abrió definitivamente y Sábat reforzó la sátira en sus caricaturas en especial contra Galtieri quien aparecía como el único responsable de la "aventura" y de la derrota. De modo simultáneo, comenzaba a construirse la imagen de víctima inocente de la manipulación política e informativa de la sociedad argentina con respecto a la guerra.

Notas

1. "Recuperación" fue el modo en que las fuerzas armadas argentinas denominaron a la ocupación de las Islas que realizaron el 2 de abril de 1982.

2. Sábat rechazó ser entrevistado para esta investigación.

3. A diferencia de Sábat, que trabaja solo con imágenes, Landrú incorporaba la caricatura personal a la viñeta humorística, lo cual implica que el efecto cómico no está únicamente en el dibujo, que exagera los rasgos del caricaturizado o apela a su animalización sino en el texto que, en forma de diálogo, acompaña a esa imagen.

4. Así se refieren a él en las Bienales de Humor e Historieta que se realizaron en Córdoba en esos años, y en la revista $\mathrm{HUM} \circledast\left(\mathrm{H} \mathrm{n}^{\circ}\right.$ 8, enero de 1979, p. 11).

5. Para un análisis más pormenorizado de la caricatura durante la dictadura militar, véase Burkart, 2014.

6. Mientras el diario La Nación, exponente de las clases altas, vendió 240.000 ejemplares en 1982, y el popular diario La Razón, 370.000 (Muraro, 1987).

7. También expresaron su apoyo quienes estaban en el exilio. En el campo intelectual, León Rozitchner, desde Venezuela, en solitario tuvo la lucidez y la audacia de oponerse a la "guerra limpia". Según su punto de vista, "el éxito del poder militar de ejército de ocupación argentino significaba la derrota del poder -moral y político y 
económico- del pueblo argentino" (Rozitchner, 2005, p. 12). De este modo, Rozitchner le respondía al Grupo de Discusión Socialista conformado por intelectuales argentinos exilados en México, como Juan Carlos Portantiero, José Aricó, Emilio de Ípola, José Nun y Néstor García Canclini, que había hecho público el documento "Por la soberanía argentina en las Malvinas: por la soberanía popular en Argentina".

8. Véase Levín (2013, pp. 213-248).

9. Para un análisis sobre la posición de HUM® ante la Guerra de Malvinas, véase Burkart, 2013.

10. Excede los límites de este trabajo analizar el regreso de Mercedes Sosa, al respecto véanse Marchini (2008, pp. 265-308) y Burkart (2011).

Bibliografía

Berger, P. (1999). Risa Redentora. La dimensión cómica de la experiencia humana. Barcelona: Kairós.

Blaustein, E. y Zubieta, M. (1998). Decíamos ayer. La prensa argentina bajo el Proceso. Buenos Aires: Colihue, .

Borrelli, M. (2010). El diario Clarín frente a la política económica de Martínez de Hoz (1976- 1981), Tesis

Doctoral, Universidad de Buenos Aires.

Burkart, M. (2014). "La caricatura política bajo la dictadura militar argentina (1976-1983)”, Contemporânea, Año 4, n4 Disponible en: http.://www.historia.uff.br/nec/revistacontemporanea

Burkart, M. (2013). "Avatares de la crítica y de la sátira: $H U M \circledR$ y la Guerra de Malvinas”, Nuevo Mundo, Mundos Nuevos, [En línea], Cuestiones del tiempo presente. Disponible en: http://nuevomundo.reveus.org/64808

Burkart, M. (2011). HUM®: la risa como espacio crítico bajo la dictadura militar, 1978-1983, Tesis de doctorado, Universidad de Buenos Aires.

Escudero, L. (1996). Malvinas: el gran relato. Fuentes y rumores en la información de guerra. Barcelona: Gedisa. Gombrich, E. ([1940] 2001). Caricature, Ross Woodrow \& The University of Newcastle, Newcastle.

Gombrich, E. (2003). "Magia, mito y metáfora. Reflexiones sobre la sátira política” en Los usos de las imágenes. Estudios sobre la función social del arte y la comunicación visual. México: FCE.

Guber, R. (2012). ¿Por qué Malvinas? De la causa nacional a la guerra absurda. Buenos Aires: FCE.

Landi, O. (compilador) (1987). Medios, transformación cultural y política. Buenos Aires: Legada.

Levín, F. (2013). Humor político en tiempos de represión. Clarín, 1973-1983. Buenos Aires: Siglo XXI.

Marchini, D. M. (2008). No toquen. Músicos populares, gobierno y sociedad/ utopía, persecución y listas negras en la Argentina 1960/1983. Buenos Aires: Catálogos. 
Muraro, H. (1987). "La comunicación masiva durante la dictadura militar y la transición democrática en la Argentina, 1973-1986” en Landi, O. (compilador), Medios, transformación cultural y política. Buenos Aires: Legada.

Novaro, M. y Palermo, V. (2003). La dictadura militar 1976-1983. Del golpe de Estado a la restauración democrática. Buenos Aires: Paidós.

Rozitchner, L. ([1982] 2005). Malvinas: de la guerra sucia a la guerra limpia. El punto ciego de la crítica política. Buenos Aires: Losada.

Sábat, H. (1971). Al troesma con cariño. Buenos Aires: Siglo XXI editores.

Sábat, H. (1981). Tango Mío. Madrid: Ameris.

Sivak, M. (2013). Clarín, el gran diario argentino. Una historia. Buenos Aires: Planeta.

Varela, M. (2013). "La Plaza de Malvinas: el color de la multitud” en Mestman, M. y Varela, M., coordinadores, Masas, pueblo, multitud en cine y televisión. Buenos Aires: Eudeba.

Fuentes

Diario Clarín de marzo a septiembre de 1982 y 11 de diciembre de 1983

Abstract: The aim of this work is to analyze the caricatures created by Hermenegildo Sábat for Clarin newspaper, during the Malvinas/Falklands conflict caused by the Argentine military dictatorship on April 1982 that ended in a clamorous defeat. Conceived in its modern sense, caricatures are a powerful and effective visual instrument to continue political conflicts by symbolic means. Since then, what happened with the caricatures during the Malvinas/Falklands war? Did they became a weapon of the nationalistic cause or were able to offer new and critical interpretations about the conflict? Our hypothesis is that Sábat's caricatures acknowledge the closure of the public space during the so-called "recuperation" and the war itself, and suggests that they could set up a critical crank.

Key words: Malvinas/Falklands War - caricature - Hermenegildo Sábat.

Resumo: Este trabalho propõe analisar os cartoons produzidos por Hermenegildo Sábat, cartunista do jornal Clarín, durante o conflito sobre as Ilhas Malvinas desencadeadas pela ditadura militar argentina em abril de 1982 e que terminou dois meses depois com uma retumbante derrota militar. Concebida no seu sentido moderno, a caricatura é um instrumento visual poderoso e eficaz quando se trata de conflitos políticos contínuos através de meios simbólicos. Então, o que aconteceu com a caricatura em um dos principais jornais nacionais durante a Guerra das Malvinas? Será que se tornou outra arma ao serviço da causa nacionalista ou permitiu interpretações novas e críticas do conflito? Nossa hipótese é que os desenhos de Sabat consideram o fechamento do espaço público entre o tempo da chamada "recuperação" e a própria guerra, e sugere-se que eles possam permitir uma lacuna crítica.

Palavras chave: Guerra de Malvinas - caricatura - Hermenegildo Sábat. 
[Las traducciones de los abstracts al inglés y portugués fueron supervisadas por el autor de cada artículo]

La Guerra de Malvinas según las Caricaturas de Hermenegildo Sábat en Clarín fue publicado de la página 17 a página32 en Cuadernos del Centro de Estudios de Diseño y Comunicación №74 